\title{
Corporate Governance and Corporate Financial Reporting: Their Impact on the Performance of Large Firms of Pakistan
}

\author{
Nadeem Ayub Bhutta \\ Assistant Professor, School of Accounting and Finance, UCP \\ nadeem.bhutta@ucp.edu.pk \\ Hafiz Ghulam Mustafa \\ Lecturer, School of Accounting and Finance, UCP \\ g.mustafa@ucp.edu.pk
}

\begin{abstract}
The aim of the study is to estimate the impact of corporate governance on the performance of large firms with mediating effect of corporate financial reporting in private listed companies of Pakistan. Survey method is adopted for data collection as this is a descriptive study. A questionnaire on the 5 point Likert scale was adopted for data collection and then distributed among employees of private listed companies of Pakistan. Regression and correlation techniques are used. Cronbach's Alpha is used to determine the reliability of questionnaire. The findings of the result reveal that corporate governance has significant impact on corporate financial reporting and in turn corporate financial reporting has significant impact on the performance of large firms of Pakistan.
\end{abstract}

Keywords: corporate governance, corporate financial reporting, performance of firms

\section{Introduction}

Corporate governance mechanisms are those mechanisms that protect shareholders interests. Country's economic development improves with the help of good corporate governance (Gul, Sajid, Razzaq, \& Afzal, 2012).It is a method of leading firms to reduce their principal agent conflicts (Iqbal \& Javed, 2017). The Pakistan code of corporate governance was published in year 2002 by the, "Securities and Exchange Commission of Pakistan", for the purpose of enhancing governance and transparency and to improve the disclosure in financial reporting of companies in order to protect the interests of companies investors.

Sound corporate governance principles are the foundation upon which the trust of investors and lenders is built. Good corporate governance practices may have significant influence on the strategic decisions of a company, e.g. external financing (Hasan \& Butt, 2009). Good corporate financial reporting is generally an indication of competitiveness and superior corporate governance (Aruwa, 2010). Financial reporting is useful because more efficient contracts are possible when contracting parties commit to a more transparent information environment (Armstrong, Guay, \& Weber, 2010).

\section{Problem Statement}

The satisfaction or dissatisfaction with corporate financial reporting is the most frequently measured reaction and previous studies has reported that there may a positive or negative relationship between corporate governance and financial reporting on performance of the firm.

However, there is lack of empirical evidence on the relationship between corporate governance and firm performance when

The current issue and full text archive of this journal is available at www.jraspublications.org/index.php/JRAS/issue/archive Journal of Research in Administrative Sciences(JRAS)

VII(I),11-13, ISSN: 2664-2433 corporate financial reporting is acting as a mediator. In this context, this paper attempts to identify, analyze and evaluate effect of corporate governance on corporate financial reporting and it's in turn effect on performance of firms of Pakistan.

\section{General Objective}

To evaluate corporate governance, and corporate financial reporting and their impact on the performance of large firms of Pakistan.

\section{Specific Objectives}

- To assess impact of corporate governance on performance of firms.

- To evaluate impact of corporate financial reporting on performance of firms.

- To determine impact of corporate governance on corporate financial reporting.

\section{Literature Review}

Corporate governance concept is considered to be an important part of strategic management. The main objective of the corporate governance is to provide good relationship among stakeholders (Oguz \& Dincer, 2016). Basically it deals with the mechanisms that ensure investors to get a return on their investments (Shleifer \& W.Vishney, 1997). Corporate governance varies widely across countries and firms. Better governance helps firms to get access to capital markets on better terms, which is valuable for firms which intend to raise funds (Doidgea, Karolyib, \& Stulzb, 2007).Corporate governance involves in fare balancing of interests 
Corporate Governance and Corporate Financial Reporting: Their Impact on the Performance of Large Firms of Pakistan

Nadeem Ayub Bhutta, Hafiz Ghulam Mustafa

between stakeholders and corporate investors in a firm. Basically it is a method of leading firms to reduce their principal agent conflicts. It also helps in providing the right direction to the firms that how the firms should work and be supervised (Iqbal \& Javed, 2017).Financial capital is a key factor of production that gives rise to an array of complex contracting relationships among owners, managers, and creditors. When structuring these contracting arrangements, divergent interests among managers, boards, equity investors, and lenders create a demand for monitoring and bonding mechanisms that help alleviate various agency conflicts (Armstrong, Guay, \& Weber, 2010).

Good corporate financial reporting is generally an indication of competitiveness and superior corporate governance (Aruwa, 2010).The better reports always address all the required relevant information in a summarized manner and disclose thoroughly the measures taken including on activities, corporate policy, strategic plans, the company's prospects and current initiatives to protect the environment (Pushpanathan). Financial reporting is useful because more efficient contracts are possible when contracting parties commit to a more transparent information environment (Armstrong, Guay, \& Weber, 2010).The annual report is a document which adds value to stakeholders. However, reporting must evolve in order to maintain and enhance its value (ACCA, 2012). It can be stressed enough that companies should be more open if they want to improve. The more relevant information it shares with its stakeholders, the better a company's corporate governance is likely to be (Aruwa, 2010).

Security Exchange Commission of Pakistan (SECP) states that whether a company is private, public, nonprofit, or government, all those charged with its governance should assess their structure and needs to develop an effective corporate governance approach. The underlying goal in a corporate governance system is to ensure that the decision makers in a company, such as its directors and management, are acting in the best interests of the company's stakeholders. SECP has issued corporate governance frameworks for designated classes of companies including listed companies, public sector companies, and insurance companies, for mandatory compliance (Security Exchange Commission of Pakistan).

Accurate and true financial information is the basis on which investment decision are made However some organizations resort to window dressing or manipulation of financial data which does not depict a true picture of the financial position of the firm. Therefore, a body like independent audit committee is required to check such unscrupulous activities (Bansal \& Sharma, 2016). Audit Committee is considered as an integral part of corporate governance because with the help of this committee faulty conduct of managers can be checked (Cowan, 2011).

So it can be concluded that corporate governance and corporate financial reporting may have a positive or negative impact on performance of Pakistani firms. The satisfaction or dissatisfaction with corporate financial reporting is the most frequently measured reaction and previous studies has reported that there may a positive or negative relationship between corporate governance and financial reporting on performance of the firm.

\section{Gap}

The effect of corporate governance on firm performance is the most frequently measured effect and studies have reported that there is a positive relationship between good corporate governance and firm's performance. However, there is lack of empirical evidence on the relationship between corporate governance and firm performance when corporate financial reporting is acting as a mediator.

\section{Research Methodology}

Primary data has been collected from private limited companies of Pakistan. Target population was managerial employees of private limited companies of Pakistan. Out of 21 companies listed in Karachi Stock Exchange under food \& care products managerial employees of 9 companies were selected as a convenient sample to make analysis. In this study independent variable is effective corporate governance practice which is measured by checking the most important mechanisms of corporate governance such as code of conduct, companies act, SEBI, statutory audit, shareholder's participation and corporate control. While dependent variable in this study is firm's performance which is measured by return on investment, revenue growth, profitability growth and goodwill. The mediating variable of the study is corporate financial reporting which is measured by degree of relevance, faithful representation, comparability, timeliness, verifiability and understandability.

According to the nature of the research objective, quantitative approach has been adopted. Quantitative survey was employed as it is the most appropriate one to use if the purpose of an investigation is to describe the relationship which exists between the variables. The research instrument used to collect primary data was structured questionnaire. Variables are measured by using 5point Likert scale because it is easy and simple for participants and likely to give more reliable results.

\section{Theoretical Framework}

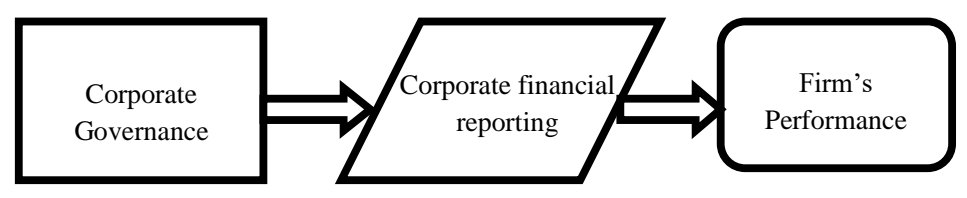

\section{Hypothesis}

H1: Corporate governance has positive impact on firm's performance.

H2: Corporate governance has negative impact on firm's performance.

H3: Corporate governance results into effective corporate financial reporting.

H4: Corporate governance results into ineffective corporate financial reporting.

H5: Corporate financial reporting has significant impact on firm's performance.

H6: Corporate financial reporting has insignificant impact on firm's performance.

\section{Data Analysis}

In this study for the reliability check Cronbach's alpha was used and the estimation of 0.6 is considered to be an acceptable value.

\begin{tabular}{lc}
\hline \multicolumn{1}{c}{ Variables } & Values \\
\hline $\begin{array}{l}\text { Corporate } \\
\text { Governance } \\
\text { Corporate Financial } \\
\begin{array}{l}\text { Reporting } \\
\text { Firm's Performance }\end{array}\end{array}$ & 0.645 \\
\hline
\end{tabular}

Descriptive statistics are used to show the essential components of the data in a review. They give basic synopses about the example and the measures. The descriptive statistics of the variables have been computed to see whether the information was useful for basic condition for demonstrating or not on the grounds that if the estimation of descriptive statistics is deviated, or the information is scattered then the after effects of structural equation modelling may not be extremely valuable. 
Corporate Governance and Corporate Financial Reporting: Their Impact on the Performance of Large Firms of Pakistan

Nadeem Ayub Bhutta, Hafiz Ghulam Mustafa

\begin{tabular}{|c|c|c|c|}
\hline Variables & Mean & Std. Deviation & Variance \\
\hline $\begin{array}{l}\text { Corporate } \\
\text { Governance }\end{array}$ & 2.7831 & 0.55643 & 0.354 \\
\hline $\begin{array}{l}\text { Corporate Financial } \\
\text { Reporting }\end{array}$ & 2.5497 & 0.82170 & 0.685 \\
\hline Firm's Performance & 2.6871 & 0.68898 & 0.420 \\
\hline \multicolumn{4}{|c|}{$\begin{array}{l}\text { The above mentioned table demonstrates the goodness of variables } \\
\text { and their reliability. PLS- } 3 \text { software was used to check the } \\
\text { structural equation modelling of the variables. The estimation of } \\
\text { Average Variance Extracted is considered to significantly affect } \\
\text { the dependent variable if the values are over } 0.5 \text { the figured vales } \\
\text { are as per the following: }\end{array}$} \\
\hline Variables & Avera & Variance Extrac & ed (AVE) \\
\hline $\begin{array}{l}\text { Corporate Governance } \\
\text { Corporate Financial } \\
\text { Reporting } \\
\text { Firm's Performance }\end{array}$ & & $\begin{array}{l}0.755 \\
0.533\end{array}$ & \\
\hline
\end{tabular}

In the above mentioned table, all the values are above the acceptable value which shows the significant influence on the variables. On the other hand, Composite Reliability was also computed to check the reliability of the variables and it should be above 0.7 , the following are the values

\begin{tabular}{lc}
\hline \multicolumn{1}{c}{ Variables } & Composite Reliability \\
\hline Corporate Governance & 0.921 \\
Corporate Financial Reporting & 0.821 \\
Firm's Performance & 0.933 \\
\hline
\end{tabular}

The values of the Composite Reliability are all above 0.7 which clearly shows that the outcomes drawn will be suitable and helpful.

\begin{tabular}{lcccc}
\hline \multicolumn{1}{c}{ Paths } & $\begin{array}{c}\text { Path } \\
\text { Coefficients }\end{array}$ & $\begin{array}{c}\text { Std. } \\
\text { Deviation }\end{array}$ & T-Statistics & $\begin{array}{c}\text { P- } \\
\text { Value }\end{array}$ \\
\hline CG - > & 0.546 & 0.204 & 2.587 & 0.010 \\
FP & & & & \\
CG - > & 0.419 & 0.162 & 2.756 & 0.006 \\
CFR & & & & \\
CFR - > & 0.224 & 0.237 & 2.427 & 0.017 \\
FP & & & & \\
$\mathbf{R}^{2}=$ & & & & \\
$\mathbf{0 . 5 4 9}^{2}$ & & & & \\
\hline
\end{tabular}

\section{Findings}

The independent variable corporate governance has significant impact on corporate financial reporting that is acting as a mediator between corporate governance and firm's performance. The research also shows that corporate financial reporting has significant impact on firm's performance. The study clearly exhibits that corporate governance has significant impact on performance of firms of Pakistan.

\section{Conclusion}

The satisfaction or dissatisfaction with corporate financial reporting is the most frequently measured reaction and previous studies has reported that there may a positive or negative relationship between corporate governance and financial reporting on performance of the firm.

However, there is lack of empirical evidence on the relationship between corporate governance and firm performance when corporate financial reporting is acting as a mediator. This research increases our understanding about impact of corporate governance on firm's performance with the mediating effect of corporate financial reporting.

\section{References}

i. ACCA. (2012). Re-assesing the value of corporate reporting.

ii. Armstrong, C. S., Guay, W. R., \& Weber, J. P. (2010). The role of information and financial reporting in corporate governance an debt contracting. MIT .

iii. Aruwa, D. S. (2010). Corporate reporting and analysis.

iv. Bansal, N., \& Sharma, A. K. (2016). Audit Committee, Corporate Governance and Firm Performance: Empirical Evidence from India. International journal of economics and finance .

v. Corporate governance and firm performance: the case for turkey (2016).

vi. Cowan, J. (2011). Research methods in education. British jounal of education technology .

vii. Doidgea, C., Karolyib, G. A., \& Stulzb, R. M. (2007). Why do countries matters so much for corporate governance? Journal of financial economics .

viii. $\quad$ Gul, S., Sajid, M., Razzaq, N., \& Afzal, F. (2012). Agency Cost, Corporate Governance and Ownership Structure. International journal of business and social science .

ix. Hasan, A., \& Butt, S. A. (2009). Impact of Ownership Structure and Corporate Governanceo on capital structure. International journal of busiess and management .

x. Iqbal, M., \& Javed, F. (2017). The moderating role of cotporate governance on the relationship between capital structure and financial performance:evidence from manufacturing sector of Pakistan. International jounal of research in business and social science.

xi. Pushpanathan, P. (n.d.). Retrieved 2010

xii. Security Exchange Commission of Pakistan. (n.d.). Retrieved from https://www.secp.gov.pk/corporategovernance/corporate-governance/

xiii. Shleifer, A., \& W.Vishney, R. (1997). A survey of corporate governance. Journal of Finance. 